\title{
Planktonic ciliates in the oligotrophic Mediterranean Sea: longitudinal trends of standing stocks, distributions and analysis of food vacuole contents
}

\author{
Paraskevi Pitta $^{1, *}$, Antonia Giannakourou $^{2}$, Urania Christaki ${ }^{2}$ \\ ${ }^{1}$ Institute of Marine Biology of Crete, PO Box 2214, 71003 Heraklion, Crete, Greece \\ ${ }^{2}$ National Centre for Marine Research, Aghios Kosmas, 16604 Hellinikon, Greece
}

\begin{abstract}
Vertical distribution, standing stocks, size-class structure, community structure, mixotrophy and cell content of ciliate assemblages were studied at 9 stations along a transect in the Mediterranean Sea in June 1999. The aim of the study was to relate the trophic conditions in the Mediterranean to the ciliate community structure and the grazing impact of ciliates. The vertical distribution was more or less uniform in the Eastern Basin but presented an extended upper layer with higher density and a maximum at 50 to $75 \mathrm{~m}$ in the Western Basin. The integrated abundance $(11.2$ to $26.9 \times 10^{6}$ cells m$^{-2}$ ) and biomass ( 41.5 to $84.8 \mathrm{mg} \mathrm{C} \mathrm{m}^{-2}$ ) decreased by a factor of 2 from west to east. A total of 55 tintinnid species were identified. Aloricates $<30 \mu \mathrm{m}$ represented $62 \%$ of integrated abundance and $16 \%$ of biomass. Mixotrophs made up $17 \%$ of integrated abundance and $18 \%$ of biomass. From west to east, there was no evident change in the structure of the ciliate community with respect to (1) aloricate size-classes, (2) mixotroph size-classes, (3) contribution of mixotrophs to total abundance. The cell content of all ciliates was examined for Synechococcus and photosynthetic algae under epifluorescence inverted microscopy. Tintinnids contained similar quantities of algae and Synechococcus $\left(1.04 \pm 0.59\right.$ algae tintinnid $^{-1}, 0.94 \pm 0.87$ Synechococcus tintinnid $\left.^{-1}\right)$ and the same was true for aloricates. Based on cell content, it was estimated that (1) the ingestion rate for tintinnids was: 0.61 photosynthetic algae $\mathrm{h}^{-1}$ and 0.41 Synechococcus $\mathrm{h}^{-1}$ and for aloricates: 0.14 photosynthetic algae $\mathrm{h}^{-1}$ and 0.13 Synechococcus $\mathrm{h}^{-1}$; (2) tintinnids ingested significantly more prey than aloricates by a factor of 5 ; and (3) ciliates consumed $26 \%$ of primary production in the Western, $41 \%$ in the Central and $70 \%$ in the Eastern Basin.
\end{abstract}

KEY WORDS: Planktonic ciliates · Mediterranean · Distributions · Mixotrophy· Size classes · Cell content Resale or republication not permitted without written consent of the publisher

\section{INTRODUCTION}

Ciliates play a major role in the transfer of energy and material through the pelagic food web (Beers \& Stewart 1967, Pierce \& Turner 1992). Planktonic ciliates are believed to feed on nanoplankton (Heinbokel \& Beers 1979, Capriulo \& Carpenter 1983, Verity 1987)

*E-mail: vpitta@imbc.gr and picoplankton (Sherr et al. 1986, Rassoulzadegan et al. 1988). In oligotrophic systems, where pico- and nanoplankton are the dominant size fractions in terms of biomass and primary productivity (Riley 1957, Li et al. 1983, Platt et al. 1983, Landry et al. 1996), ciliates and heterotrophic flagellates are expected to be the main grazers since copepods are unable to crop these size classes efficiently (Marshall 1973).

Platt (1985) has expressed doubts on the use of the term 'oligotrophic' in the marine environment since it 
is not clear whether it refers to low autotrophic biomass, low nutrient concentration, or low specific growth rates. No matter what the definition is, the Mediterranean exhibits a noticeable gradient of increasing oligotrophy from west to east, in terms of nutrient concentration (Krom et al. 1991), primary productivity (Turley et al. 2000) and autotrophic biomass (Dolan et al. 1999). Therefore, the Mediterranean Sea represents a system-model in which one can study the influence of trophic conditions on the structuring of the food web.

Some information on ciliate distribution (Rassoulzadegan 1977, 1979, Revelante \& Gilmartin 1990, Bernard \& Rassoulzadegan 1994, Dolan \& Marrasé 1995, Krsinic 1995, Pitta \& Giannakourou 2000) or ciliate grazing and growth (Rassoulzadegan 1982, Sherr et al. 1989, Ferrier \& Rassoulzadegan 1991, Pérez et al. 1997, Christaki et al. 1999) is now available, mainly from the Western and Central Basins. However, little is known about ciliate trophic modes (mixotrophy, heterotrophy) and size classes (nano-, micro-) which coexist within the food web and may take advantage of different food resources. Since in oligotrophic environments food is not only limited but also partitioned in terms of size, potential changes in ciliate community structure may affect the grazing impact of these organisms.

During a recent study of planktonic ciliates in the Mediterranean (Dolan et al. 1999), the Eastern Basin was found to contain a more diverse tintinnid community. In the Eastern Mediterranean, Pitta \& Giannakourou (2000) have shown that $36 \%$ of ciliate abundance were smaller than $18 \mu \mathrm{m}$, of which $33 \%$ were mixotrophic.

The grazing impact and feeding activity of planktonic ciliates have been investigated in many studies (Pierce \& Turner 1992 and references therein) using different approaches, either offering labeled or unlabeled prey, or prey analogues to single ciliate species (Rassoulzadegan 1982, Jonsson 1986, Bernard \& Rassoulzadegan 1990, Kivi \& Setälä 1995) or using the dilution method (Landry \& Hassett 1982) at the community level (Burkill et al. 1987, Paranjape 1987, Gifford 1988, Stelfox-Widdicombe et al. 2000). The cell content method has been employed in laboratory experiments to estimate ingestion and digestion of single species of ciliates (Dolan \& Coats 1991, Dolan \& Šimek 1997). It has also been used to assess the role of tintinnids as primary production consumers (Kopylov \& Tumantseva 1987), to estimate the partitioning of the food ration of oligotrichs between pico- and nanoplankton (Rassoulzadegan et al. 1988) and to assess the role of picoplankton in the diet of tintinnids (Bernard \& Rassoulzadegan 1993). The last 2 studies have been carried out in coastal waters and have examined part of the ciliate community, either oligotrichs or tintinnids. To our knowledge, this technique has not been previously used to estimate the grazing impact of the entire ciliate community in field samples.

Thus, the purpose of the present study was to examine the structure of the ciliate community along the Mediterranean Sea with emphasis on trophic modes (heterotrophy, mixotrophy) and size structure (nano-, micro-). Particular effort was made to estimate the consumption of primary production by the entire ciliate community and to relate changes in ciliate community structure to the grazing impact. To this end, the cell content method was used in field samples, and ciliate ingestion on photosynthetic prey (Synechococcus and photosynthetic algae) was estimated by enumeration of this prey in every single ciliate cell encountered in the samples.

\section{MATERIALS AND METHODS}

In June (7 to 28) 1999, 9 stations (Stns S1 to S9) were sampled in the Mediterranean Sea along a west-east transect (5 to $35^{\circ} \mathrm{E}$, Fig. 1). All stations were established offshore, at bottom depths ranging from 1300 (Stn S7) to $4030 \mathrm{~m}$ (Stn S6). Samples were collected around midday $(12: 00 \mathrm{~h}$, local time) at a 1, 10, 20,50, $75,100,120,150$ and $200 \mathrm{~m}$ water depth, by means of a CTD-rosette using $10 \mathrm{l}$ Go-Flo bottles. Profiles of water-column structure (temperature and salinity) were performed with a Seabird CTD profiler and in situ fluorescence was recorded with a Chelsea in situ fluorometer.

For ciliate enumeration, $500 \mathrm{ml}$ of whole water was preserved with borax-buffered formaldehyde (final concentration $2 \%$ ). The samples were stored at $4^{\circ} \mathrm{C}$ in the dark and examined within 3 mo of collection. Before examination, samples were left to settle in their bottles in the dark at $4^{\circ} \mathrm{C}$ and after $48 \mathrm{~h}$, the top $400 \mathrm{ml}$ of the sample was slowly siphoned off. The bottom $100 \mathrm{ml}$ of the sample was transferred into settling chambers, allowed to settle for $24 \mathrm{~h}$ and was finally examined with an Olympus IX-70 inverted microscope at $200 \times$. The microscope was equipped for transmitted light, phase-contrast and epifluorescence microscopy. Blue light excitation (DM $500 \mathrm{~nm}$ dichroic mirror, BP 420 to $480 \mathrm{~nm}$ exciter filter, BA $515 \mathrm{~nm}$ barrier filter and a $100 \mathrm{~W}$ mercury burner) was used to detect chlorophyll autofluorescence and to distinguish plastidic from non-plastidic ciliates. Examination of the supernatant (top $400 \mathrm{ml}$ of sample siphoned) showed minimal cell loss (0 to $6 \%$ ) during the above sample concentration process.

A problem associated with the preservative choice is the possibility of affecting the apparent importance of 


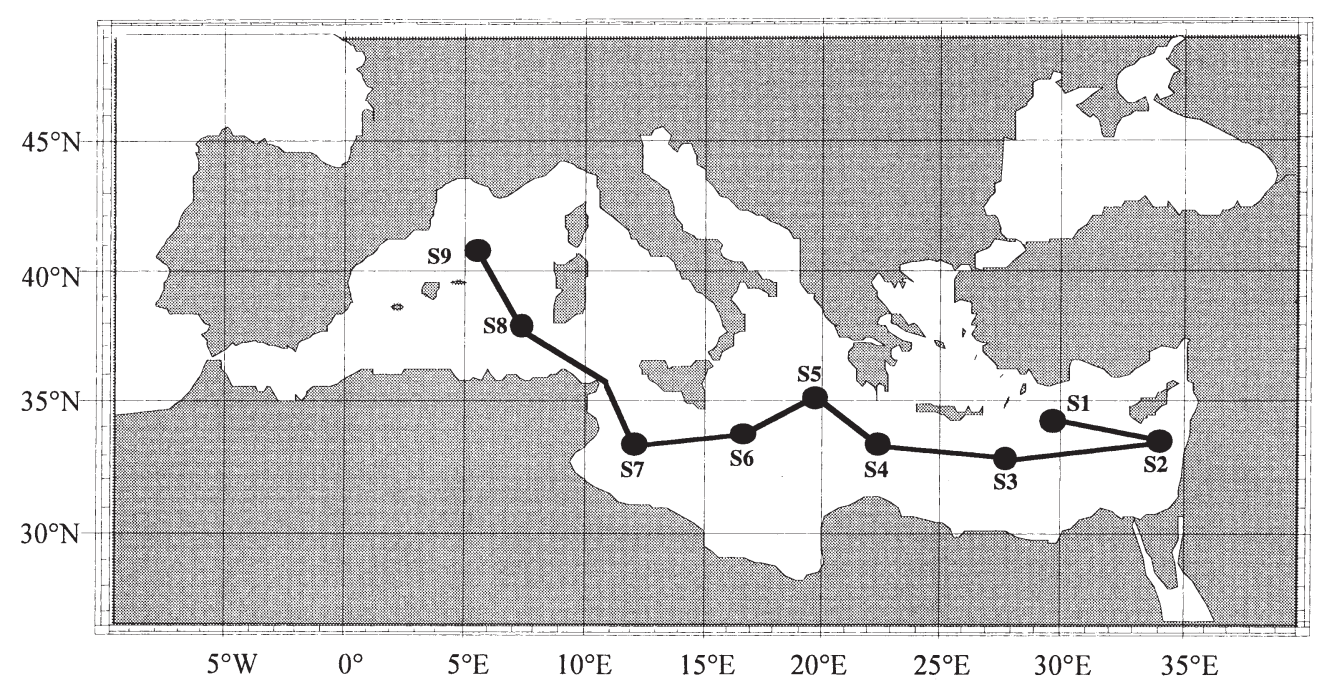

Fig. 1. Sampling stations in the Mediterranean Sea during the TransMediterranean sampling cruise (June 1999)

loricate and aloricate ciliates since tintinnids are expected to be more robust to preservation. Buffered formaldehyde (final concentration $2 \%$ ) is often used especially when we need to know about the trophic status of ciliates. Stoecker et al. (1989) established that samples preserved in buffered formaldehyde lost 10 to $20 \%$ of aloricate ciliates compared to samples preserved in acid Lugol's iodine solution, whereas Revelante \& Gilmartin (1983) estimated this loss to be 30 to $70 \%$. In this study, duplicate samples taken from 4 stations and 3 depths were fixed with both formaldehyde and acid Lugol's iodine solution. When samples were analysed within a 3 mo period, no significant differences in aloricate numbers were found between samples fixed with either of the 2 fixatives (ANOVA, $p>$ 0.05). However, after that period, the aloricate population in formaldehyde samples showed a reduction of 30 to $59 \%$ compared to Lugol's (A. Giannakourou unpubl. data).

In this study, the orders Oligotrichida, Choreotrichida and Tintinnida (Laval-Peuto 1994, Laval-Peuto et al. 1994) are studied. The first 2 comprise aloricate and the third loricate species. Ciliates other than choreotrichs are not presented in this study since at all stations they comprised less than $1 \%$ of total abundance. Plastidic ciliates are those species retaining plastids (some members of the order Oligotrichida), while the terms mixotrophic and heterotrophic describe the trophic activity of the various ciliate speciesthis being both phagotrophic and phototrophic in the case of mixotrophs, and phagotrophic only in the case of heterotrophs. The term nanociliates is used to describe the aloricate species smaller than $18 \mu \mathrm{m}$.

Oligotrich and choreotrich ciliates were identified down to genus or species level where possible, follow- ing Maeda \& Carey (1985), Maeda (1986), Laval-Peuto \& Rassoulzadegan (1988), Lynn et al. $(1988,1991)$, Montagnes et al. $(1988,1990)$, and Montagnes \& Taylor (1994). Tintinnids were identified to species level, based on the lorica shape and dimensions after Jørgensen (1924) and Balech (1959).

Cell sizes were measured with an ocular micrometer and converted into cell volumes using appropriate geometric formulae (Peuto-Moreau 1991). According to Stoecker et al. (1992), the factors used to convert biovolumes to biomass are influenced by taxon as well as the fixation method. During this study, the conver-

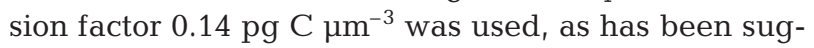
gested for ciliates fixed with $2 \%$ formaldehyde (Putt \& Stoecker 1989).

During observation, all ciliates were examined for fluorescent prey. Under blue light, 2 kinds of prey, Synechococcus (Syn, orange fluorescence) and photosynthetic algae ( $\mathrm{PN}$, red fluorescence) were visible within the ciliates. For each sample, the average number of prey (calculations were performed separately for Syn and PN) per ciliate (aloricate or tintinnid separately) was estimated as

$$
\begin{gathered}
{\left[\left(x_{0} \times 0\right)+\left(x_{1} \times 1\right)+\left(x_{2} \times 2\right)+\left(x_{3} \times 3\right)+\ldots+\left(x_{n} \times n\right)\right] /} \\
\left(x_{0}+x_{1}+x_{2}+x_{3}+\ldots+x_{n}\right)
\end{gathered}
$$

where $x_{0}, x_{1}, x_{2}, x_{3}, \ldots, x_{n}=$ the number of ciliates containing $0,1,2,3, \ldots, n$ prey respectively. Within the ciliate cells, we were able to reliably distinguish up to 12 PN and 14 Syn.

The number of prey per ciliate was not found to be significantly different among sampling depths at the stations examined (2-way ANOVA, $p>0.309)$. Therefore, it was decided to calculate a single value for each station taking into account all depths. To this end, val- 
ues were weighted for the abundance encountered at different depth layers

$$
S=\frac{\sum_{i=1}^{200} p_{i} \times c_{i}}{\sum_{i=1}^{200} c_{i}}
$$

where $S=$ average prey content in the station, $C_{i}=$ number of ciliates at depth $i$, and $p_{i}=$ average number of fluorescent prey per ciliate at depth $i$.

The ingestion rate (IR) of ciliates on PN or Syn (prey number ciliate ${ }^{-1} \mathrm{~h}^{-1}$ ) was calculated according to Sherr et al. (1988) as modified by Dolan \& Šimek (1997).

$$
\begin{aligned}
I R= & (\text { cell content at steady state }) \times \\
& (\text { digestion rate } k)
\end{aligned}
$$

A digestion rate $(k)$ of $0.924 \%$ cell content $\mathrm{min}^{-1}$ was used. This digestion rate corresponds to a mean half food vacuole passage time of $75 \mathrm{~min}$ as determined by Dolan \& Šimek (1997) for Strombidium sulcatum grazing on a series of different prey (fluorescent microspheres, Synechococcus and Isochrysis galbana). Regarding tintinnid species, in the only existing study, Kopylov \& Tumantseva (1987) experimentally calculated a similar half digestion time of approximately $1 \mathrm{~h}$ $(60 \pm 10 \mathrm{~min})$ for 2 tintinnid species feeding on algae. Since no other studies exist on the digestion rate of photosynthetic prey by ciliates, we used Dolan \& Šimek's figure $\left(0.924 \%\right.$ cell content $\left.\mathrm{min}^{-1}\right)$ for the entire ciliate community.

During counting, all ciliates containing fluorescent prey were identified as tintinnids or aloricates and further divided into 2 size categories $<$ or $>30 \mu \mathrm{m}$ according to their lorica diameter or cell length respectively. Ingested prey was also divided into 2 size categories $(<$ or $>3 \mu \mathrm{m})$ according to their diameter. Synechococcus was assigned to the small size category. The cases where more than 1 prey category was found inside a predator cell were taken into account separately; only presence or absence of prey was marked, irrespective of the number of prey found.

Two-way ANOVA (station by depth) was used in order to test for significant differences among samples grouped according to depth or longitude. In order to test whether the factors investigated (longitude, depth) had an impact on the community structure (affecting the species composition and/or the relative abundance of the species present) multivariate analysis was performed on the tintinnid species abundance data using non-metric multidimensional scaling (MDS, Field et al. 1982) in the PRIMER software package. Similarities among samples were calculated by means of the BrayCurtis index (Bray \& Curtis 1957), and a $\log (x+1)$ transformation was applied on the abundance data prior to analysis in order to normalize data and avoid skew- ness. Multivariate analysis was performed only on tintinnid data since this group can serve as 'ideal' organisms for the study of changes in the composition of microzooplankton communities (Thompson et al. 1999). Cumulative plots of species numbers versus cumulative numbers of individuals were plotted for all the stations sampled using the 'nested design' as recommended by Rosenzweig (1995).

\section{RESULTS}

\section{Vertical distribution, standing stocks, size-classes and mixotrophy}

The water column was characterized by the seasonal thermocline. Fluorescence profiles during the cruise indicated a well-established deep chlorophyll maximum (DCM, Fig. 2). The fluorescence maximum was detected at $130 \mathrm{~m}$ in the furthest east (Levantine Basin, Stn S2) and at $60 \mathrm{~m}$ at the furthest west (northwestern Mediterranean, Stn S9) of the transect.

Ciliate density ranged from 4 to 350 cells $\mathrm{l}^{-1}$. Maximal density was encountered at Stn S8, at 50 m depth. In the Eastern Mediterranean, Stns S1 and S2 showed a more or less uniform vertical distribution of ciliates in the upper $150 \mathrm{~m}$ layer with low abundance, a slight maximum at $75 \mathrm{~m}$ and a slight decrease below $150 \mathrm{~m}$ (Fig. 2). Stns S3, S4 and S5 presented a more pronounced subsurface maximum at $75 \mathrm{~m}$ depth and values decreased below this depth. The vertical distribution at Stns S6, S7, S8 and S9 in the Western Basin showed an extended upper layer characterized by high density and maxima at 50 or $75 \mathrm{~m}$; density decreased sharply below $100 \mathrm{~m}$. Maxima of DCM and ciliate abundance coincided more or less in the Western Basin but not in the Eastern one.

Ciliate abundance, integrated to $200 \mathrm{~m}$ depth, decreased by a factor of 2 along the longitudinal transect from west to east: $23.5 \times 10^{6}$ cells $\mathrm{m}^{-2}$ at Stn S9, $11.2 \times 10^{6}$ cells m${ }^{-2}$ at Stn $\mathrm{S} 1$ (Fig. 3A). The same was found to hold true for ciliate biomass, integrated to 200 m depth: $84.8 \mathrm{mg} \mathrm{C} \mathrm{m}^{-2}$ at Stn S9, $41.5 \mathrm{mg} \mathrm{C} \mathrm{m}^{-2}$ at Stn S1 (Fig. 3B).

Aloricate species dominated the depth-integrated total ciliate abundance and biomass (Fig. 3A,B). Their relative contribution to total ciliate abundance varied from 59 to $93 \%$ (mean $77 \%$ ) and to total ciliate biomass from 49 to $88 \%$ (mean $60 \%$ ). Among heterotrophic aloricates, Lohmaniella ovalis, Strombidium sphaericum, L. spiralis and S. compressum were the most abundant species and among mixotrophs Tontonia simplicidens, S. vestitum, T. ovalis and S. delicatissimum. Tintinnids were a less important group numerically but due to their large size they comprised an 

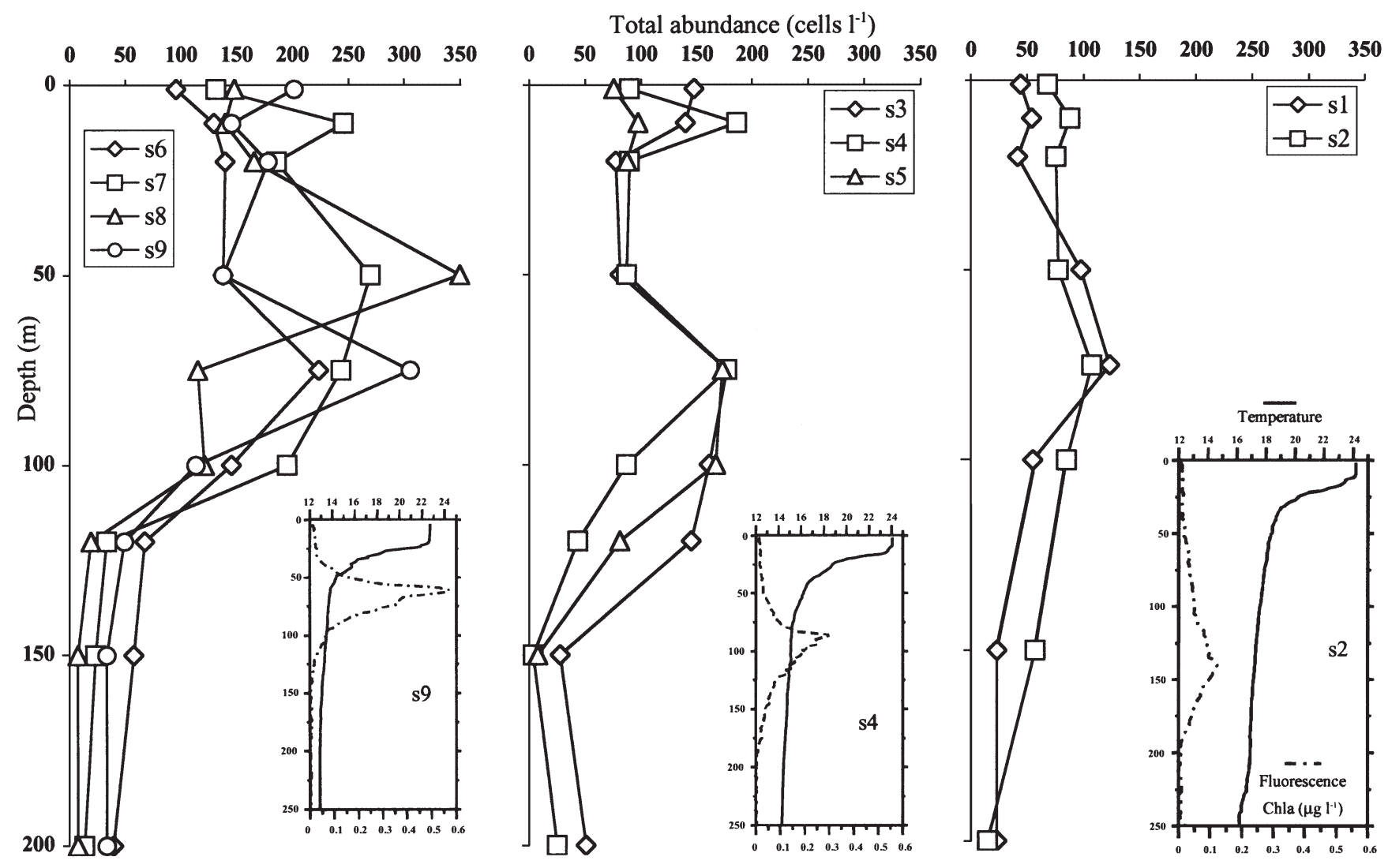

Fig. 2. Total ciliate abundance (cells $1^{-1}$ ) versus depth at all stations sampled. For each group of stations, representative profiles are given of temperature $\left({ }^{\circ} \mathrm{C}\right)$ and fluorescence chlorophyll $a$

important part of the total biomass (up to $54 \%$ at Stns S2 and S3). The most abundant tintinnids were Amphorella amphora, Dictyocysta mitra var. minor, Dadayiella ganymedes, Salpingella decurtata and Undella clevei.

Nanociliates (aloricate species <18 $\mu \mathrm{m}$ ) comprised, on average, $23 \%$ of aloricate abundance at the stations sampled and $62 \%$ were species smaller than $30 \mu \mathrm{m}$ (Fig. 4A). However, in terms of biomass, the contribution of species smaller than 18 and $30 \mu \mathrm{m}$ to total aloricates was less important (2 and $16 \%$ respectively). Along the transect, from west to east, there was no evident change in the structure of the aloricate community in respect of size-classes (Fig. 4A); 18 to $30 \mu \mathrm{m}$ species were the most abundant aloricates at all the stations sampled in terms of integrated abundance. However, the percentage contribution of the $<30 \mu \mathrm{m}$ aloricates to total aloricate abundance, calculated per depth stratum and averaged over all 9 sampling stations along the Mediterranean transect, increased with depth, from $54 \%$ at $1 \mathrm{~m}$ to $81 \%$ at $200 \mathrm{~m}$ (Fig. 4B). The same was found to hold true for biomass.

Mixotrophs comprised an important part of the ciliate fauna at the stations sampled, on average $17 \%$ of integrated abundance and $18 \%$ of integrated biomass. Their percentage contribution to total abundance and biomass was more or less the same along the longitudinal transect, i.e. $16 \%$ of biomass in the east and $23 \%$ in the west (Fig. 3A,B). Mixotrophic ciliates decreased with depth, especially below $100 \mathrm{~m}$, mainly in terms of biomass; above this depth layer, their distribution was more or less homogeneous (Fig. 3C,D). Along the longitudinal transect, there was no spectacular change in terms of size-class structure of the mixotrophic community (Fig. 4C). However, the percentage contribution of the $<30 \mu \mathrm{m}$ mixotrophs to total mixotrophic abundance, calculated per depth stratum and averaged over all 9 sampling stations along the Mediterranean transect, increased with depth, from $32 \%$ at $10 \mathrm{~m}$ to $69 \%$ at $150 \mathrm{~m}$ (Fig. 4D).

\section{Spatial patterns and community structure}

Stns S1 and S9 were found to be significantly different (ANOVA, p < 0.05) in terms of total ciliate and tintinnid abundance. Stns S1 and S2 differed significantly $(p<0.05)$ from Stn S7 in terms of total ciliate, 


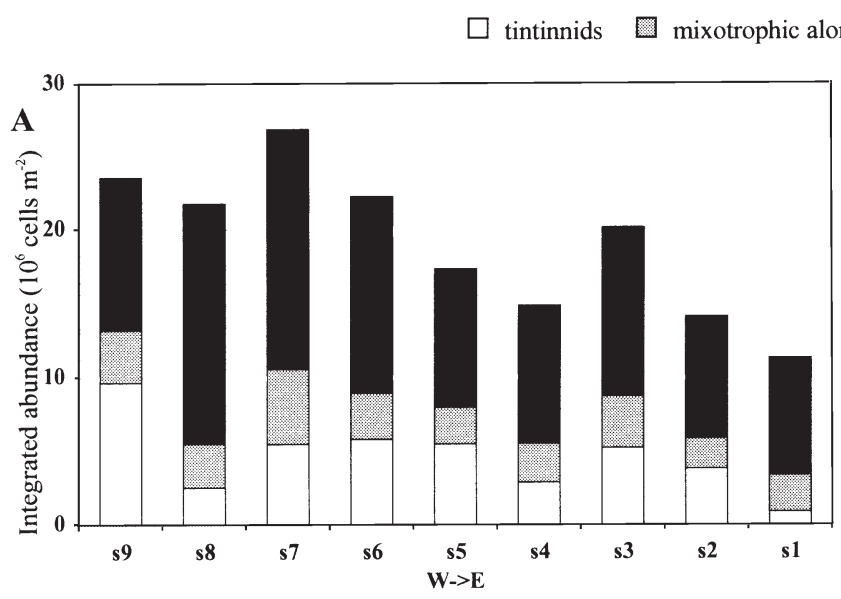

\footnotetext{
heterotrophic aloricates
}

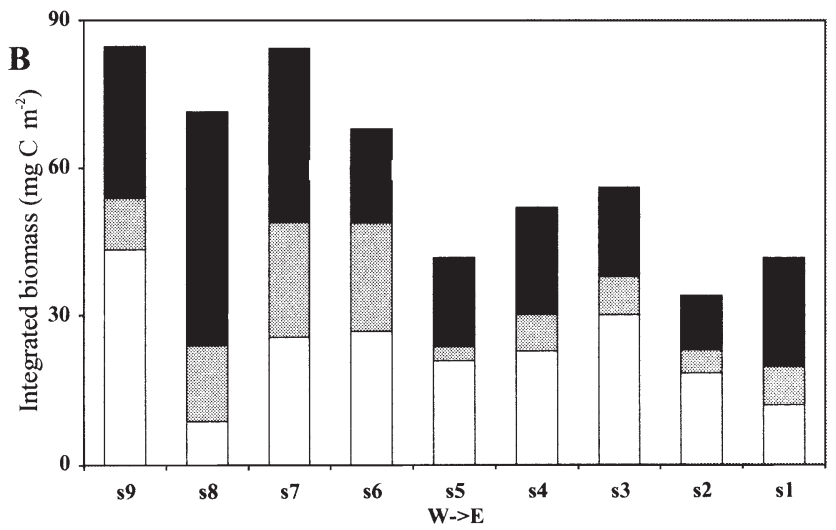

C

Abundance

$\mathbf{D}$
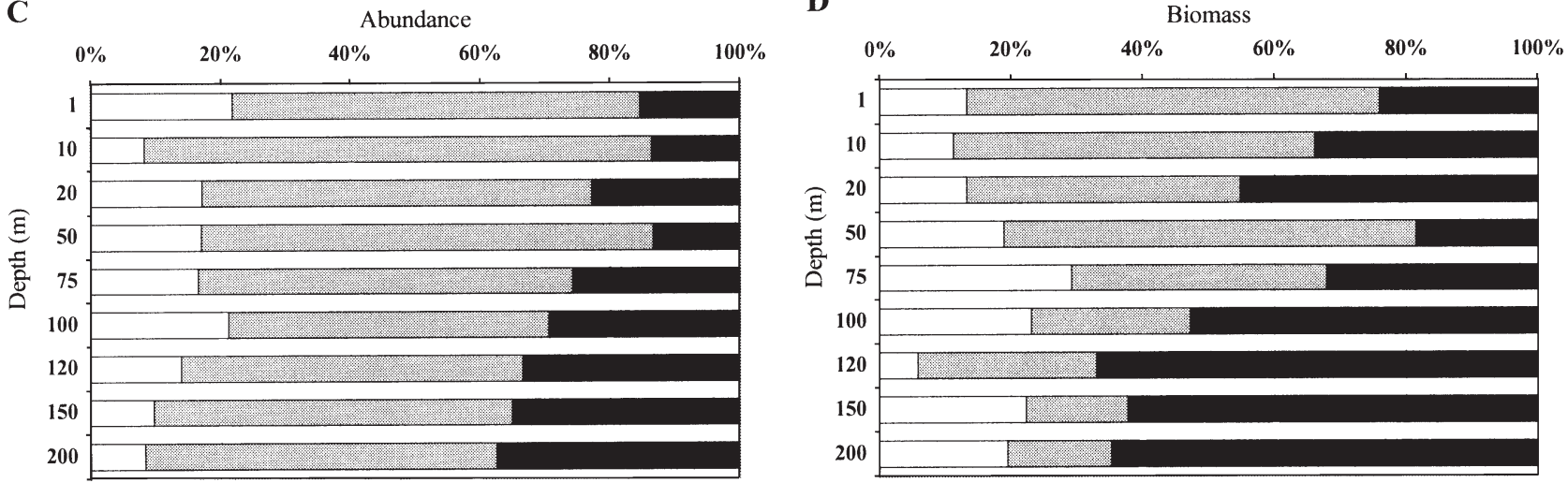

Fig. 3. (A) Integrated abundance $\left(10^{6}\right.$ cells $\left.\mathrm{m}^{-2}\right)$ and (B) integrated biomass $\left(\mathrm{mg} \mathrm{C} \mathrm{m}^{-2}\right)$ of tintinnids, heterotrophic aloricates and mixotrophic aloricates at all stations sampled. Percentage contribution of (C) abundance and (D) biomass of tintinnids, heterotrophic aloricates and mixotrophic aloricates to total abundance, calculated per depth stratum and averaged over all 9 stations along the Mediterranean transect

aloricate, heterotrophic aloricate abundance as well as in terms of 18 to $30 \mu \mathrm{m}$ aloricates.

Significant differences among depths were detected for different components of ciliate fauna in terms of abundance. Namely, concentrations of total ciliates, aloricates, heterotrophs and almost all size-classes of aloricates differed between the upper (down to $100 \mathrm{~m}$ ) and the lower layers $(p<0.05)$. In other cases, such as tintinnids or various size-classes of aloricates or mixotrophs, differences were detected only between some depths without any evident trend.

Among the 55 tintinnid species identified (Table 1), 14 were found at only 1 station, two-thirds of the species in less than half of the stations and only 1 species (Dadayiella ganymedes) was present at all 9 stations. On average, the most dominant species at each station accounted for $16 \%$ of the total tintinnid abundance and the first 2 species for $29 \%$ (ranging from 21 to $44 \%$ ).

In terms of species numbers, the tintinnid assemblages did not present a substantial difference along the Mediterranean transect (Fig. 5A). Stn S1 showed the lowest number of tintinnid species but also the lowest abundance. However, the cumulative number of tintinnid species versus cumulative number of tintinnids plotted for all stations sampled (all depths pooled within each station) from east to west as well as from west to east (Fig. 5B) presented different patterns: when going from west to east, there were continuously new species encountered in the samples whereas few species were added to the species list when tracking the opposite direction, east to west.

On the other hand, multivariate analysis (MDS, stress $=0.2$ ) of tintinnid species-abundance data for all the samples examined revealed no evident clustering or any detectable longitudinal differences with respect to community structure (Fig. 5C). This fact implies that the tintinnid community structure (which largely reflects the abundance of the most abundant species) was not substantially different along the Mediterranean transect, from west to east, nor was 

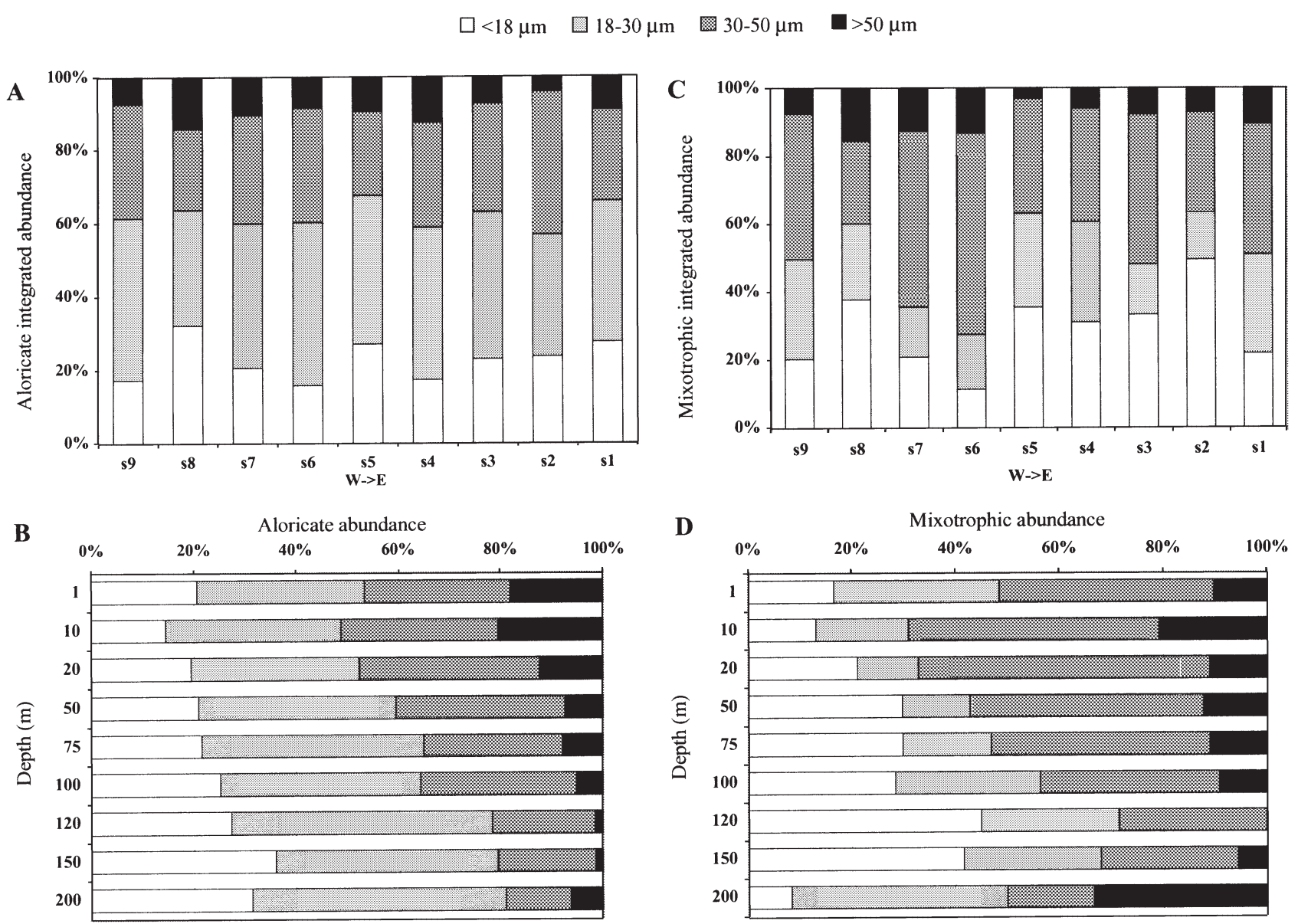

Fig. 4. Percentage contribution of (A) 4 aloricate size-classes to total aloricate integrated abundance at all stations sampled, (B) different aloricate size-classes to total aloricate abundance, calculated per depth stratum and averaged over all 9 stations along the Mediterranean, (C) 4 mixotrophic size-classes to total mixotrophic integrated abundance at all stations sampled, (D) different mixotrophic size-classes to total mixotrophic abundance, calculated per depth stratum and averaged over all 9 stations along the Mediterranean

there any pronounced qualitative difference with depth.

\section{Cell content of aloricates and tintinnids}

All specimens (more than 4100) encountered in the samples were examined for fluorescent prey. The average number of prey (Syn or PN) per ciliate (aloricate or tintinnid) was estimated for each station (Table 2). No obvious pattern, quantitative or qualitative, was observed along the Mediterranean transect (ANOVA, p > 0.05). Tintinnids contained similar numbers of PN and Syn per individual (ANOVA, p > 0.05), i.e. $1.04 \pm 0.59 \mathrm{PN}_{\text {tintinnid }}{ }^{-1}$ and $0.94 \pm 0.87 \mathrm{Syn}$ tintinnid $^{-1}$; this was found to hold true for the aloricates as well: $0.22 \pm 0.14 \mathrm{PN}$ aloricate $^{-1}$ and $0.28 \pm$ 0.26 Syn aloricate $^{-1}$. However, tintinnids ingested more prey (PN or Syn) than aloricates (ANOVA, p < 0.05), by a factor of 5 .

Fig. 6 shows the distribution of the number of ingested prey items per individual ciliate. In most cases, both aloricates and tintinnids contained a few prey whereas some individuals, mainly tintinnids, contained numerous prey, mostly flagellates.

\section{Ingestion rate}

The cell content of tintinnids and aloricates showed no difference from station to station along the Mediterranean transect (Table 2). Consequently, neither did the ingestion rate (Table 2) of both groups (ANOVA, $p>0.05)$, the estimation of which was based on the cell content (Eq. 3). Aloricates and tintinnids presented similar ingestion rates for PN and Syn (ANOVA, p > 
Table 1. Percentage of abundance of tintinnid species at all stations sampled. Stations are arranged from west to east and species are sorted according to their presence-absence in the west-east gradient. $+:<1 \%$

\begin{tabular}{|c|c|c|c|c|c|c|c|c|c|}
\hline \multirow[t]{2}{*}{ Species } & \multirow[b]{2}{*}{ Stn S9 } & \multirow[b]{2}{*}{ Stn S8 } & \multirow[b]{2}{*}{ Stn S7 } & \multicolumn{3}{|c|}{$\%$ of tintinnid abundance } & \multirow[b]{2}{*}{ Stn S3 } & \multirow[b]{2}{*}{ Stn S2 } & \multirow[b]{2}{*}{ Stn $\mathrm{S} 1$} \\
\hline & & & & Stn S6 & Stn S5 & Stn S4 & & & \\
\hline Undella hyalina & 1 & & & & & & & & \\
\hline Helicostomella subulata & & 1 & & & & & & & \\
\hline Epiplocylis acuminata & + & & & 1 & & & & & \\
\hline Salpingella acuminata & + & 3 & & & 4 & & & & \\
\hline Amphorella oxyura & 2 & 4 & 1 & & & 1 & & & \\
\hline Dictyocysta elegans var. lepida & 1 & & & 1 & 3 & & & & \\
\hline Parundella lohmanni & 1 & & & 1 & 1 & & & & \\
\hline Dictyocysta mitra var. minor & 19 & 3 & 1 & & 10 & 6 & & & \\
\hline Rhabdonella spiralis & 1 & 6 & 9 & & 2 & 6 & & & \\
\hline Amphorella amphora & 25 & & 2 & 4 & & 3 & & & \\
\hline Parundella minor & & 6 & & & 1 & & & & \\
\hline Tintinnid sp. $35 \mu \mathrm{m}$ & & 3 & & & 5 & & & & \\
\hline Protorhabdonella curta & + & 1 & 1 & 3 & 1 & & 2 & & \\
\hline Amphorella torulata & 3 & 10 & 18 & 7 & 5 & 8 & 4 & & \\
\hline Eutintinnus elegans & 3 & 6 & 4 & 2 & 1 & 11 & 1 & & \\
\hline Salpingella subconica & + & & & & & & 1 & & \\
\hline Undellopsis marsupialis & & & & 1 & & & & & \\
\hline Eutintinnus fraknoi & & & & 1 & & & & & \\
\hline Codonella galea & & & & 1 & & & & & \\
\hline Parundella aculeata & & 3 & & 1 & 3 & 3 & & & \\
\hline Amphorella pachytoecus & 2 & 3 & 1 & 5 & 7 & & 6 & 5 & \\
\hline Dictyocysta elegans var. speciosa & 3 & & & & 1 & & 2 & & \\
\hline Acanthostomella minutissima & & 12 & & & 3 & 3 & & & \\
\hline Salpingella decurtata & 4 & 9 & 14 & 6 & 4 & 6 & 12 & 11 & \\
\hline Steenstrupiella steenstrupii & 3 & 12 & 11 & 4 & 7 & 1 & 5 & 3 & \\
\hline Amphorella quadrilineata var. minor & 2 & & 4 & 2 & 2 & 3 & & 3 & \\
\hline Amphorella pyramidata & & & & 3 & 1 & & & & \\
\hline Amphorella quadrilineata & & & & 1 & 1 & & & & \\
\hline Proplectella claparedei & 3 & & 6 & 4 & & & 9 & 6 & \\
\hline Eutintinnus tubulosus & 6 & 3 & 3 & 8 & 1 & 4 & 2 & & 8 \\
\hline Dadayiella ganymedes & 12 & 3 & 17 & 10 & 13 & 6 & 4 & 9 & 8 \\
\hline Undella subacuta f. acuta & & 3 & 4 & & 2 & 3 & & & 15 \\
\hline Stenosemella nivalis & & & & & 1 & & & & \\
\hline Favella azorica & & & & & 1 & & & & \\
\hline Codonaria cistellula & & & & & 1 & & & & \\
\hline Salpingella curta & 1 & & & & 2 & & 3 & 2 & \\
\hline Eutintinnus apertus & + & & 4 & 4 & & & 7 & 5 & 8 \\
\hline Dictyocysta mitra f. obtusa & & & 1 & & & 3 & 4 & & \\
\hline Salpingella rotundata & 1 & 4 & & & & 1 & 1 & 2 & 8 \\
\hline Salpingella glockentögeri & 4 & & & 3 & 1 & & 6 & 2 & 8 \\
\hline Eutintinnus lusus-undae & & 4 & & & & 6 & 6 & 3 & \\
\hline Xystonella longicauda & & & & 2 & 2 & 7 & 6 & 9 & \\
\hline Canthariella truncata & & & & & & 1 & & & \\
\hline Amphorella urceolata & & & & 3 & & & 2 & 3 & \\
\hline Xystonella treforti & & & & 2 & & 3 & & & 15 \\
\hline Undella clevei & & & & 21 & 7 & 10 & 13 & 19 & 15 \\
\hline Epiplocylis undella var. blanda & & & & & & 1 & 1 & & \\
\hline Rhabdonella elegans & & & & & & 6 & 3 & 11 & \\
\hline Proplectella parva & & & & & 2 & & & & 8 \\
\hline Rhabdonella amor & & & & & & & 1 & & \\
\hline Favella ehrenbergii & & & & & & & 1 & & \\
\hline Climatocylis scalaria & & & & & & & 1 & & \\
\hline Xystonellopsis paradoxa & & & & & 1 & & & 3 & 8 \\
\hline Protorhabdonella simplex & & & & & & & & 2 & \\
\hline Tintinnopsis orientalis & & & & & & & & 3 & \\
\hline
\end{tabular}

0.05). On average, the ingestion rate for aloricates was: $0.14 \pm 0.08 \mathrm{PN}$ aloricate ${ }^{-1} \mathrm{~h}^{-1}$ and $0.13 \pm 0.10$ Syn aloricate $^{-1} \mathrm{~h}^{-1}$ and for tintinnids: $0.61 \pm 0.42 \mathrm{PN}_{\text {tintinnid }}{ }^{-1}$ $\mathrm{h}^{-1}$ and $0.41 \pm 0.53$ Syn tintinnid ${ }^{-1} \mathrm{~h}^{-1}$. However, the ingestion rate of tintinnids for either prey was 3 to 4 times higher than that of aloricates. 


\section{Size relationships between predator and prey}

A high proportion $(88 \%)$ of aloricates $<30 \mu \mathrm{m}$ was found to contain small prey items $<3 \mu \mathrm{m}$; only $8 \%$ of small aloricates ingested large prey $>3 \mu \mathrm{m}$ whereas $4 \%$ contained small and large prey simultaneously (Table 3). As for aloricates 30 to $50 \mu \mathrm{m}, 62 \%$ ingested small prey, $27 \%$ ingested large prey and $12 \%$ small and large prey simultaneously. Tintinnids $<30 \mu \mathrm{m}$ in diameter, ingested small prey $(80 \%)$, large prey $(15 \%)$ or both simultaneously $(6 \%)$. The selection of larger tintinnid species was wider: $54 \%$ ingested small prey, $29 \%$ large prey and $17 \%$ ingested large and small prey simultaneously.

\section{DISCUSSION}

\section{Ciliate distribution and community structure in the Mediterranean Sea}

The west-east trophic gradient in the Mediterranean reported in previous studies regarding nutrients (Béthoux et al. 1992), chl a (Dolan et al. 1999) and primary productivity (Turley et al. 2000) was also reflected in ciliate abundance and biomass. The integrated abundance and biomass of total ciliate in the Western Basin were double the values in the Eastern Mediterranean. Another aspect of the longitudinal gradient concerned the vertical ciliate distribution. In the Eastern Basin, the distribution of total ciliates was relatively uniform down to $200 \mathrm{~m}$. However, in the western part the maximum ciliate abundance seemed to follow the chlorophyll fluorescence maximum (shallower compared to east, Fig. 2) and showed pronounced density in the upper layer (50 to $75 \mathrm{~m}$ ). However, while quantitatively a gradient was found with total ciliate abundance and biomass decreasing from west to east, the qualitative attributes of the offshore ciliate communities were found to be rather uniform throughout the Mediterranean in terms of the size and trophic mode structure and species composition.

This is the first study to report ciliate community composition throughout the Mediterranean in terms of size-classes. The size-class structure of aloricates including mixotrophic species was more or less similar throughout the Mediterranean, which was true for the size structure of ciliate prey ( $\mathrm{PN}$ and heterotrophic algae, HN) as well (Christaki et al. in press). Small algal cells $(<3 \mu \mathrm{m})$ dominated from west to east $(68 \pm 12$ and $74 \pm 10 \%$ of PN and HN). On the other hand, nanociliates accounted for $23 \%$ of integrated abundance and the species $<30 \mu \mathrm{m}$ dominated the total abundance $(62 \%)$. Nanociliates were also found to form an important part of the ciliate community in the Eastern
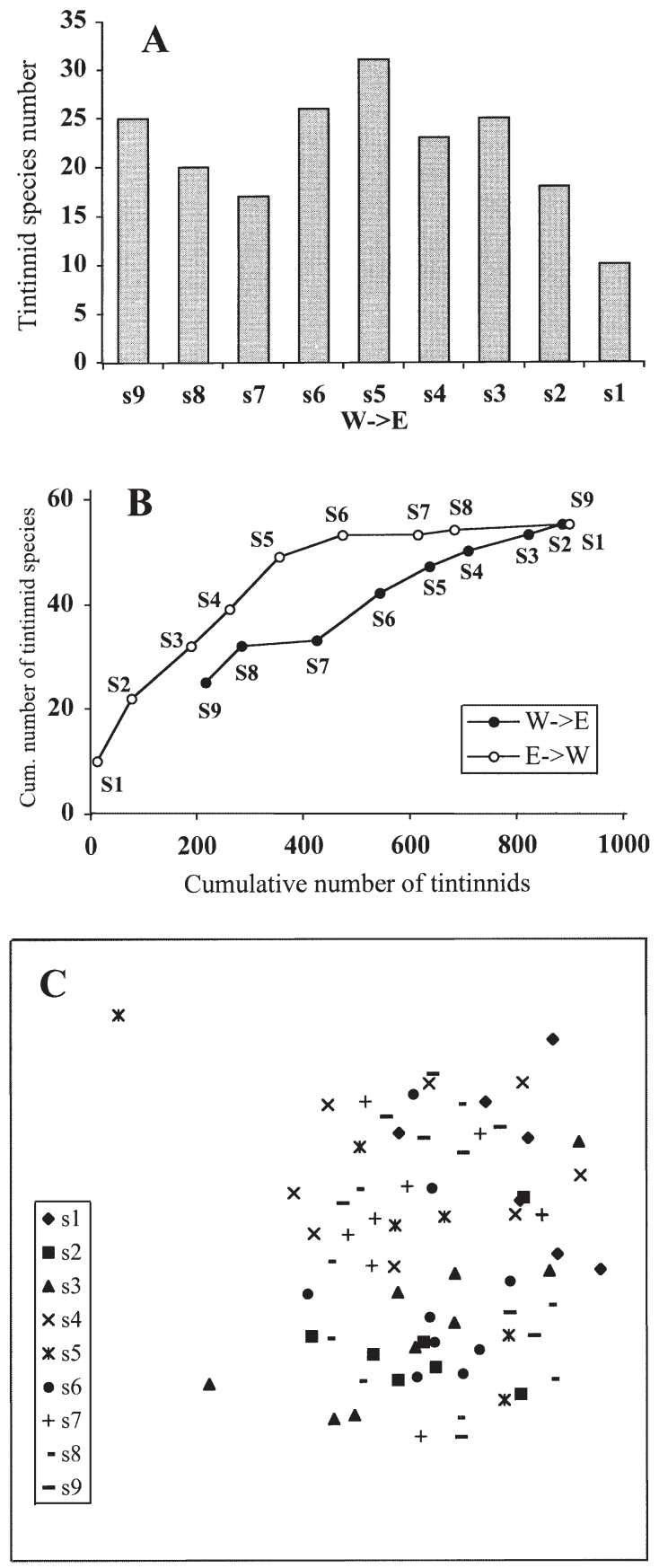

Fig. 5. (A) Species number of tintinnids encountered at the stations sampled, (B) cumulative number of species versus cumulative number of individuals for tintinnids sampled at all stations (all depths pooled within each station) along the Mediterranean Sea. The figure is plotted in 2 directions, eastward and westward. (C) Multidimensional scaling ordination plot of tintinnid species-abundance data at all stations and in all depths along the Mediterranean Sea. Stress $=0.2$

Mediterranean as was reported for the Aegean Sea by Pitta \& Giannakourou (2000). The Mediterranean Sea showed similarities from west to east not only in terms 
Table 2. Numbers of fluorescent prey (PN [photosynthetic algae] or Syn [Synechococcus]) found per ciliate cell (tintinnid or aloricate) and ingestion rate (prey ciliate ${ }^{-1} \mathrm{~h}^{-1}$ ) of tintinnids and aloricates. Numbers are averaged for each station (all depths pooled, values weighted for the abundance encountered in different depth layers)

\begin{tabular}{|c|c|c|c|c|c|c|c|c|}
\hline \multirow[t]{3}{*}{ Stn } & \multicolumn{4}{|c|}{ No. fluorescent prey found per ciliate cell } & \multicolumn{4}{|c|}{ Ingestion rate (prey ciliate ${ }^{-1} \mathrm{~h}^{-1}$ ) } \\
\hline & \multicolumn{2}{|c|}{ Tintinnids } & \multicolumn{2}{|c|}{ Aloricates } & \multicolumn{2}{|c|}{ Tintinnids } & \multicolumn{2}{|c|}{ Aloricates } \\
\hline & $\mathrm{PN}$ & Syn & $\mathrm{PN}$ & Syn & $\mathrm{PN} \mathrm{h}^{-1}$ & Syn $h^{-1}$ & $\mathrm{PN} \mathrm{h}^{-1}$ & Syn $h^{-1}$ \\
\hline S1 & 0.60 & 2.20 & 0.12 & 0.28 & 0.48 & 1.70 & 0.10 & 0.20 \\
\hline S2 & 0.62 & 0.04 & 0.24 & 0.03 & 0.37 & 0.01 & 0.18 & 0.02 \\
\hline S3 & 1.30 & 0.17 & 0.27 & 0.04 & 1.14 & 0.14 & 0.19 & 0.02 \\
\hline $\mathrm{S} 4$ & 1.86 & 1.90 & 0.33 & 0.38 & 1.05 & 0.46 & 0.28 & 0.16 \\
\hline S5 & 0.52 & 1.79 & 0.20 & 0.80 & 0.19 & 0.59 & 0.12 & 0.32 \\
\hline S6 & 0.36 & 0.25 & 0.06 & 0.09 & 0.16 & 0.10 & 0.05 & 0.06 \\
\hline S7 & 1.65 & 0.09 & 0.04 & 0.04 & 1.11 & 0.04 & 0.02 & 0.02 \\
\hline S8 & 1.73 & 1.33 & 0.48 & 0.54 & 0.83 & 0.47 & 0.23 & 0.16 \\
\hline S9 & 0.76 & 0.64 & 0.26 & 0.28 & 0.20 & 0.17 & 0.11 & 0.16 \\
\hline Average & 1.04 & 0.94 & 0.22 & 0.28 & 0.61 & 0.41 & 0.14 & 0.13 \\
\hline $\mathrm{SD}$ & 0.59 & 0.87 & 0.14 & 0.26 & 0.42 & 0.53 & 0.08 & 0.10 \\
\hline
\end{tabular}

of size structure but trophic mode structure as well, since there was no evident change in the contribution of mixotrophs to total abundance or biomass. The size structure of mixotrophs was also homogeneous along the Mediterranean transect, indicating that mixotrophy is not directly related to trophic conditions.

Furthermore, regarding community structure, the number of tintinnid species was more or less similar from west to east and the multivariate analysis of spe-
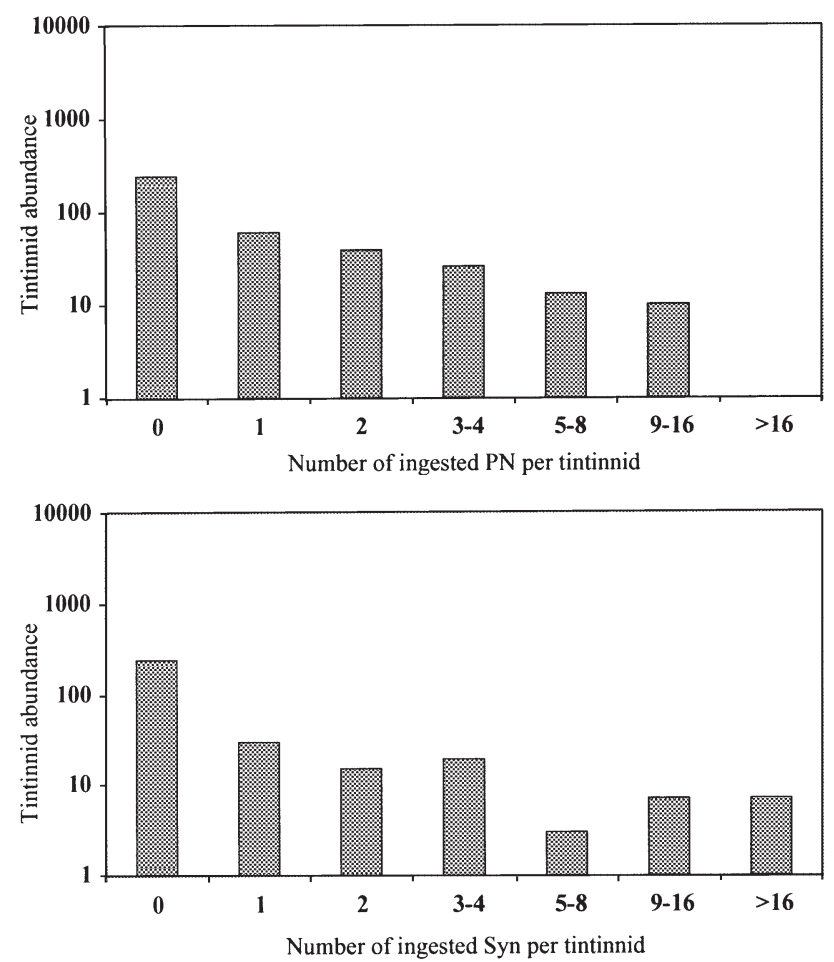

cies-abundance data for tintinnids did not reveal any evident clustering corresponding to longitudinal differences. The slightly higher number of species found by Dolan et al. (1999) might be attributed to the within species variability of tintinnids in terms of sizes and shapes of loricae which has led to a proliferation of described species (Pierce \& Turner 1993). The tintinnid species list of the present study, while reporting fewer species than those found in Dolan et al. (1999), is, how-
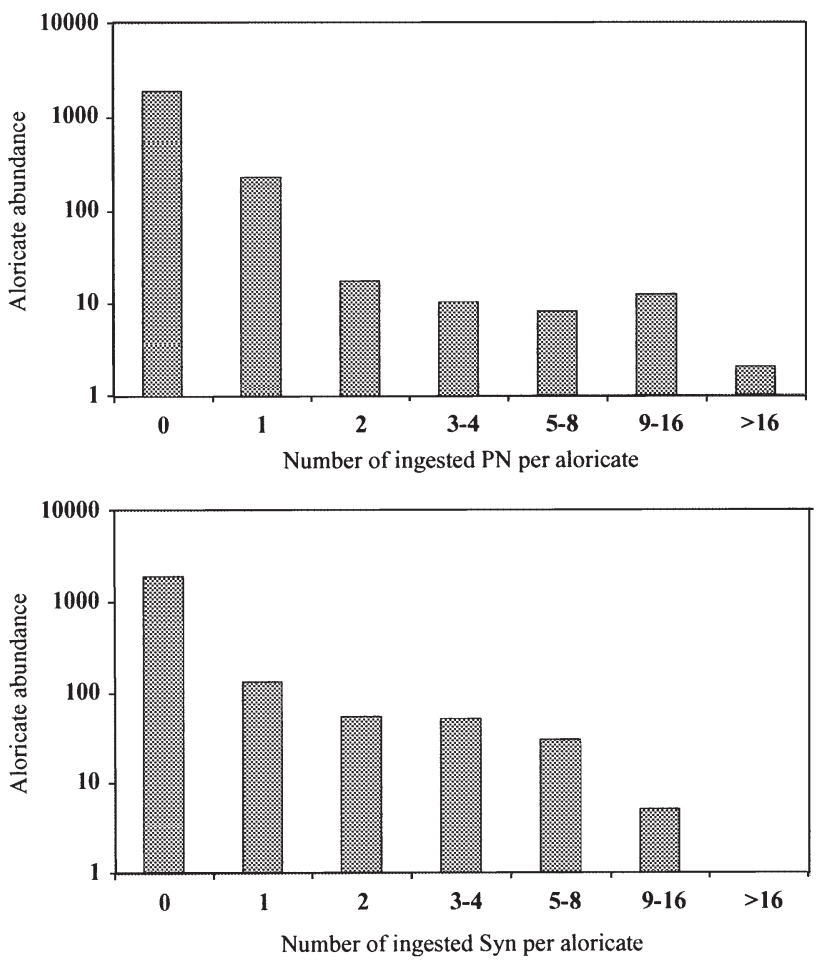

Fig. 6. Distribution of the number of ingested prey items (PN or Syn) per individual ciliate (tintinnids or aloricates) 
ever, more consistent with the ones in other studies previously undertaken in the Mediterranean such as Kimor \& Wood (1975), Rassoulzadegan (1979), Krsinic (1982, 1995), and Abboud-Abi Saab (1989).

MDS analysis (which takes into account differences between samples in terms of abundance and species composition) revealed no longitudinal trends along the Mediterranean transect in terms of tintinnid community structure. Although these differences were not detectable when taking account of individual samples, the cumulative curves of species numbers against cumulative numbers of individuals (Fig. 5B) showed there is indeed an increasing 'endemic diversity' when moving eastward as suggested by Dolan et al. (1999). According to Gray (2000), species richness can be compared only between similar spatial scales. In this context, comparisons among diversity in the Catalan Sea or the Bay of Villefranche (no matter how intensive the sampling effort was) and sampling along a biogeographical province such as the Mediterranean Sea (Cariou et al. 1999, Dolan 2000) are simply comparisons between different scales of diversity. On the other hand, when the scales involved are similar (despite the lower spatial resolution in our sampling design), the results of the present study are fairly comparable in terms of species richness to those found by Dolan et al. (1999).

\section{Ingestion of ciliates relative to prey size}

When all ciliates were included in the analysis and the number of prey was counted per individual ciliate, it was found that both prey categories (PN and Syn) were present in equal numbers in the food vacuoles of both tintinnids and aloricates (Table 2). Since the concentration of PN in the field was from 1 to 2 orders of magnitude lower than that of Synechococcus $\left(10^{2}\right.$ to $10^{3}$ and $10^{3}$ to $10^{4} \mathrm{ml}^{-1}$ respectively, Christaki et al. in press), it would be reasonable to suggest that either there was an apparent selection for algal cells or the digestion rate of these 2 prey categories is unequal. The former explanation seems more likely because Stoecker (1988) has suggested that many marine planktonic ciliates are selective grazers and Dolan \& Šimek (1997) have measured similar digestion rates for Strombidium sulcatum fed with Synechococcus and algae.

Our data clearly showed that a large proportion of the 'non-empty' ciliates (54 to $88 \%$ ), irrespective of groups (aloricates and tintinnids) or size ( $>$ or $<30 \mu \mathrm{m}$ in length or lorica diameter), contained small prey $(<3 \mu \mathrm{m})$. The occurrence of large prey in ciliates increased by a factor of 2 when passing from small to large tintinnids and by a factor of 3 when passing from small to large aloricates. However, the proportion of PN $>3 \mu \mathrm{m}$ in the water column did not exceed $5 \%$ of PN plus Syn, in any of the
Table 3. Relationship between the size and the predator group and the size of the prey. Values are \% of ciliates (tintinnids or aloricates) containing fluorescent prey; only presence or absence of prey was marked, independently of the number of prey found in each cell

\begin{tabular}{|lccc|}
\hline Predator & \multicolumn{3}{c|}{ Prey } \\
& $<3 \mu \mathrm{m}$ & $>3 \mu \mathrm{m}$ & $>3+<3 \mu \mathrm{m}$ \\
\hline Tintinnids & 63.5 & 23.8 & 12.7 \\
$\begin{array}{l}\text { Aloricates } \\
\text { Tintinnids, } \\
\text { lorica diameter }<30 \mu \mathrm{m}\end{array}$ & 79.4 & 14.7 & 5.9 \\
$\begin{array}{l}\text { Tintinnids, } \\
\text { lorica diameter }>30 \mu \mathrm{m}\end{array}$ & 54.0 & 29.2 & 16.8 \\
$\begin{array}{l}\text { Aloricates, } \\
\text { length }<30 \mu \mathrm{m}\end{array}$ & 87.9 & 8.1 & 4.0 \\
$\begin{array}{l}\text { Aloricates, } \\
\text { length }>30 \mu \mathrm{m}\end{array}$ & 61.2 & 25.7 & 13.1 \\
\hline
\end{tabular}

stations visited (Christaki et al. in press). Thus, the occurrence of prey $>3 \mu \mathrm{m}$ in large ciliates is far higher than anticipated, providing a strong indication of selectivity of larger ciliates for larger prey.

The issue of the optimum size of prey a ciliate predator can ingest has been addressed in many experimental studies where prey of different size was offered to the predator organism (Table 4). However, all these studies are laboratory experiments and it is reasonable to expect that conditions in such experiments are different from those prevailing in the field, where multispecies predator and prey communities and a whole continuum of sizes are the rule. In a study focusing on the natural oligotrich community and examining the food vacuoles, Rassoulzadegan et al. (1988) found that a large percentage of aloricates $<30 \mu \mathrm{m}$ contained picosized prey $(72 \%)$, while this decreased to $30 \%$ for 30 to $50 \mu \mathrm{m}$ species. The results of our study, referring to the entire natural ciliate community, at first seem to oppose those of the previous study since small prey remains the choice of the $>30 \mu \mathrm{m}$ aloricates to a large degree $(61 \%)$. However, the results of both studies reflect environmental conditions: our study refers to open waters, where Synechococcus dominate the phytoplankton community, whereas Rassoulzadegan et al. (1988) refer to the coastal environment, where photosynthetic algae are much more abundant than in oceanic waters.

Dolan \& Marrasé (1995) considered that nanociliates in oceanic waters may be less important than in coastal environments, both as a component of the food web and as competitors of microflagellates for picoplanktonic prey. In the present study however, aloricates $<30 \mu \mathrm{m}$ represented $62 \%$ of integrated abundance, $88 \%$ of which ingested prey $<3 \mu \mathrm{m}$. So, it seems that nanociliates may indeed be the competitors of nanoflagellates in the open Mediterranean Sea. 
Table 4. Minimum, optimum and size range of prey ingested by ciliates

\begin{tabular}{|c|c|c|c|c|}
\hline \multirow[t]{2}{*}{ Predator } & \multicolumn{3}{|c|}{ Prey size $(\mu \mathrm{m})$} & \multirow[t]{2}{*}{ Source } \\
\hline & Size range & Min. size & Optimum size & \\
\hline Tintinnopsis subacuta & & 1 & $3-8$ & Blackbourn (1974) \\
\hline Other tintinnid species & $1-5$ or less & No min. & & \\
\hline Favella ehrenbergii & & $3-4$ & & Rassoulzadegan (1978) \\
\hline Stenosemella ventricosa & $1.3-27$ & & $3-12$ & Rassoulzadegan \& Etienne (1981) \\
\hline Tintinnids & & 2 & & Spittler (1973) \\
\hline Oligotrichs & $2-50$ & & & Smetacek (1981) \\
\hline Tintinnids & $2-30$ & & $<10$ & Rassoulzadegan et al. (1988) \\
\hline Oligotrichs $<20 \mu \mathrm{m}$ & Pico- & & & \\
\hline Oligotrichs $>50 \mu \mathrm{m}$ & Nano- & & & \\
\hline Tontonia appendiculariformis & $2-15$ & & & \\
\hline Strombidium sulcatum & $0.6-6.6$ & & 2.5 & Bernard \& Rassoulzadegan (1990) \\
\hline Strombidium vestitum & & & 2.1 & Jonsson (1986) \\
\hline Strombidium reticulatum & & & 7.9 & \\
\hline Lohmaniella spiralis & & & 9.7 & \\
\hline
\end{tabular}

\section{Consumption of primary production}

Measures of primary production made during the sampling cruise (K. Pagou \& O. Gotsis-Skretas, National Center for Marine Research, unpubl. data) showed a gradient from west to east: primary production measured 21.29, 11.24 and $5.87 \mathrm{mg} \mathrm{C} \mathrm{m}^{-2} \mathrm{~h}^{-1}$ in the West, Central and East Basin respectively. Using these data and our estimates of ciliate ingestion rate, we calculated that the ciliate community consumed daily $26 \%$ of the primary production in the Western, $41 \%$ in the Central and $70 \%$ in the Eastern Mediterranean Sea.

Previous studies of primary production consumption by ciliates in different environments vary from $<10$ to $>100 \%$ (Table 5). In the Mediterranean, our estimates for the Western Basin are remarkably close to those of Dolan \& Marrasé (1995). The theoretical estimates of consumption by ciliates on primary production, reported in a recent study (Dolan et al. 1999), were much lower than the ones measured in our study, especially in the Eastern Mediterranean; however, both studies seem to be in agreement regarding the increasing importance of ciliates as primary production consumers eastwards.

Primary production was size fractionated: the $<1.2 \mu \mathrm{m}$ fraction measured 8.37 and $3.11 \mathrm{mg} \mathrm{C} \mathrm{m}^{-2} \mathrm{~h}^{-1}$ and the $>1.2 \mu \mathrm{m}$ fraction measured 12.92 and $2.76 \mathrm{mg}$ $\mathrm{C} \mathrm{m}^{-2} \mathrm{~h}^{-1}$ in the West and East Basin respectively. We assigned the $<1.2 \mu \mathrm{m}$ fraction to picoplankton, mainly Synechococcus and Prochlorococcus, and the larger fraction to algae. Based on these data, we estimated that ciliates consumed $32 \%$ of the algal production in the Western, $45 \%$ in the Central and $121 \%$ in the Eastern Mediterranean Sea whereas the values for the picoplankton production consumed by ciliates were 17, 36 and $25 \%$ in the Western, Central and Eastern Basins respectively. It is perhaps worth noting that the proportion of the Synechococcus production consumed by ciliates should be substantially higher than the above-mentioned values as, in our calculation of ciliate consumption, we could not take into account Prochlorococcus, the production of which is included in the value of picoplankton production $(<1.2 \mu \mathrm{m})$.

The results of the present study imply that ciliates consume a relatively small part of the autotrophic picoplankton production (17 to $36 \%$ ), which is higher in the Eastern Basin by a factor of 1.5 to 2 compared to the Western one. In contrast, they consume quite an important part of the algal production, especially in the Eastern Mediterranean, where they have the potential to graze $121 \%$ of the algal production. Besides, analysis of the ciliate cell content suggests selectivity for algal cells.

Overall, the data of the present study underline the crucial importance of ciliates in channeling a part of this small-sized primary production to higher trophic levels, especially in the ultra-oligotrophic Eastern Basin.

Acknowledgements. The authors wish to thank the co-ordinator of the cruise Dr V. Lykousis as well as the Captain and the crew of the RV 'Aegaeo'. Thanks are due to Drs A. Theocharis and S. Kioroglou for CTD data and to Drs K. Pagou and O. Gotsis-Skretas for primary production data. This study is contribution No. 43 to the MTP-II project 'MATER: Mass Transfer and Ecosystem Response' jointly funded by the European Commission's Marine Science and Technology III (MAST-III) Programme (contract: MAS3-CT96-0051) and the Greek General Secretariat of Research and Technology. 
Table 5. Consumption by ciliates on phytoplankton. PP: primary production

\begin{tabular}{|c|c|c|c|}
\hline System & Consumption by ciliates & Method used & Source \\
\hline Long Island Sound, USA & $43 \%$ of annual PP & Theoretical estimation & Riley (1956) \\
\hline $\begin{array}{l}\text { Southern California Bight, } \\
\text { neritic }\end{array}$ & $7-52 \%$ of $\mathrm{PP}$ & Theoretical estimation & Beers \& Stewart (1971) \\
\hline $\begin{array}{l}\text { Southern California Bight, } \\
\text { neritic }\end{array}$ & Tintinnids: $4-20 \%$ of PP & Extrapolation from lab expt & Heinbokel \& Beers (1979) \\
\hline $\begin{array}{l}\text { Long Island Sound, USA, } \\
\text { coastal }\end{array}$ & $\begin{array}{l}6 \text { of algal stock daily (at } 1 \% \text { light level) } \\
15 \% \text { of algal stock daily (at surface) }\end{array}$ & Size-fractionation method & Capriulo \& Carpenter (1980) \\
\hline Mediterranean & $59 \%$ of algal crop & Coulter Counter & Rassoulzadegan \& Etienne (1981) \\
\hline Solent, UK & Tintinnids: $60 \%$ of annual PP & Extrapolation from lab expt & Burkill (1982) \\
\hline $\begin{array}{l}\text { Off Washington coast, } \\
\text { coastal }\end{array}$ & $\begin{array}{l}-24 \% \text { of phytopl. standing stock daily } \\
17-52 \% \text { of PP daily }\end{array}$ & Dilution method & Landry \& Hassett (1982) \\
\hline Central Long Island Sound & $27 \%$ of annual PP & Extrapolation from lab expt & Capriulo \& Carpenter (1983) \\
\hline Halifax & $\begin{array}{c}-124 \% \text { of standing stock } \\
56 \% \text { of PP }\end{array}$ & Dilution method & Gifford (1985) \\
\hline Celtic Sea, coastal & $13-30 \%$ of standing stock daily & Dilution method & Burkill et al. (1987) \\
\hline Celtic Sea, offshore & $42-65 \%$ of standing stock daily & & \\
\hline Jones Sound, Arctic & $\begin{array}{l}8-15 \% \text { of standing stock daily } \\
40-114 \% \text { of PP daily }\end{array}$ & Dilution method & Paranjape (1987) \\
\hline Baffin Bay, Arctic & $9-15 \%$ of standing stock daily & & \\
\hline Peru upwelling & innids: $0.4-38 \%$ of PP daily (mean: $7 \%$ ) & Cell content & Kopylov \& Tumantseva (1987) \\
\hline Halifax Harbour & $\%$ of phytopl. stock, $47-55 \%$ of PP daily & Dilution method & Gifford (1988) \\
\hline $\begin{array}{l}\text { West Mediterranean, } \\
\text { coastal }\end{array}$ & $\begin{array}{l}9-52 \% \text { of nanoplankton } \\
\text { production }\end{array}$ & $\begin{array}{l}\text { Cell content and } \\
\text { Coulter Counter }\end{array}$ & Rassoulzadegan et al. (1988) \\
\hline $\begin{array}{l}\text { Chesapeake Bay, USA, } \\
\text { estuary }\end{array}$ & $\begin{array}{l}17-87 \% \text { of standing stock, } \\
45-102 \% \text { of PP daily }\end{array}$ & Dilution method & Gallegos (1989) \\
\hline Subarctic Pacific, offshore & $1-77 \%$ of PP & Theoretical estimation & Strom et al. (1993) \\
\hline Hiroshima Bay & $29-45 \%$ of phytopl. stock daily & Dilution method & Kamiyama (1994) \\
\hline West Mediterranean, offshore & $\begin{array}{c}25 \% \text { of PP (surface) } \\
40 \% \text { of PP (DCM) }\end{array}$ & Theoretical estimation & Dolan \& Marrasé (1995) \\
\hline Antarctic, offshore & $4-56 \%$ of PP & Theoretical estimation & Klaas (1997) \\
\hline Mediterranean, offshore & $\begin{array}{l}14 \% \text { West, } 29 \% \text { Central, } \\
23 \% \text { East of PP daily }\end{array}$ & Theoretical estimation & Dolan et al. (1999) \\
\hline $\begin{array}{l}\text { Ligurian Sea, Mediterranean, } \\
\text { nearshore }\end{array}$ & $8-40 \%$ of PP daily & Theoretical estimation & Pérez et al. (2000) \\
\hline Gironde estuary, Atlantic, coastal & $99 \%$ of PP daily & Dilution method & Sautour et al. (2000) \\
\hline $\begin{array}{l}\text { Temperate, sub-tropical NE Atlantic, } \\
\text { offshore }\end{array}$ & $\begin{array}{c}60 \text { North: } 77 \% \text { of } \\
\text { chl stock daily } \\
37 \text { North: }<44 \% \text { of } \\
\text { chl stock daily }\end{array}$ & Dilution method & Stelfox-Widdicombe et al. (2000) \\
\hline Mediterranean, offshore & $\begin{array}{l}26 \% \text { West, } 41 \% \text { Central, } \\
70 \% \text { East of PP daily }\end{array}$ & Cell content & This study \\
\hline
\end{tabular}

\section{LITERATURE CITED}

Abboud-Abi Saab M (1989) Distribution and ecology of tintinnids in the plankton of Lebanese coastal waters (eastern Mediterranean). J Plankton Res 11:203-222

Balech E (1959) Tintinnoinea del Mediterraneo. Trabajos del Instituto Espanol de Oceanografia, Madrid, No 28

Beers JR, Stewart GL (1967) Micro-zooplankton in the euphotic zone at five locations across the California Current. J Fish Res Board Can 24:2053-2068

Beers JR, Stewart GL (1971) Micro-zooplankters in the plankton communities of the upper waters of the eastern tropical Pacific. Deep-Sea Res 18:861-883

Bernard C, Rassoulzadegan F (1990) Bacteria or microflagellates as a major food source for marine ciliates: possible implications for the microzooplankton. Mar Ecol Prog Ser 64:147-155
Bernard C, Rassoulzadegan F (1993) The role of picoplankton (cyanobacteria and plastidic picoflagellates) in the diet of tintinnids. J Plankton Res 15:361-373

Bernard C, Rassoulzadegan F (1994) Seasonal variations of mixotrophic ciliates in the northwest Mediterranean Sea. Mar Ecol Prog Ser 108:295-301

Béthoux JP, Morin P, Madec C, Gentili B (1992) Phosphorus and nitrogen behaviour in the Mediterranean Sea. DeepSea Res 39:1641-1654

Blackbourn DJ (1974) The feeding biology of tintinnid Protozoa and some other inshore microzooplankton. $\mathrm{PhD}$ thesis, University of British Columbia, Vancouver

Bray JR, Curtis JT (1957) An ordination of the upland forest communities of southern Wisconsin. Ecol Monogr 27: 325-349

Burkill PH (1982) Ciliates and other microplankton components of a nearshore food-web: standing stocks and pro- 
duction processes. Ann Inst Océanogr Paris 58:335-350

Burkill PH, Mantoura RFC, Llewellyn CA, Owens NJP (1987) Microzooplankton grazing and selectivity of phytoplankton in coastal waters. Mar Biol 93:581-590

Capriulo GM, Carpenter EJ (1980) Grazing by 35 to $202 \mu \mathrm{m}$ Micro-zooplankton in Long Island Sound. Mar Biol 56: 319-326

Capriulo M, Carpenter EJ (1983) Abundance, species composition and feeding impact of tintinnid micro-zooplankton in Central Long Island Sound. Mar Ecol Prog Ser 10: $277-288$

Cariou JB, Doan JR, Dallot S (1999) A preliminary study of tintinnid diversity in the NW Mediterranean Sea. J Plankton Res 21:1065-1075

Christaki U, Jacquet S, Dolan JR, Vaulot D, Rassoulzadegan F (1999) Growth and grazing on Prochlorococcus and Synechococcus by two marine ciliates. Limnol Oceanogr 44: 52-61

Christaki U, Giannakourou A, Van Wambeke F, Grégori G (in press) Nanoflagellate predation on auto- and heterotrophic picoplankton in the oligotrophic Mediterranean Sea. J Plankton Res

Dolan JR (2000) Tintinnid ciliate diversity in the Mediterranean Sea: longitudinal patterns related to water column structure in late spring-early summer. Aquat Microb Ecol 22:69-78

Dolan JR, Coats DW (1991) Preliminary prey digestion in a predacious estuarine ciliate and the use of digestion data to estimate ingestion. Limnol Oceanogr 36:558-565

Dolan JR, Marrasé C (1995) Planktonic ciliate distribution relative to a deep chlorophyll maximum: Catalan Sea, N.W. Mediterranean, June 1993. Deep-Sea Res 42:1965-1987

Dolan JR, Śimek K (1997) Processing of ingested matter in Strombidium sulcatum, a marine ciliate (Oligotrichida). Limnol Oceanogr 42:393-397

Dolan JR, Vidussi F, Claustre H (1999) Planktonic ciliates in the Mediterranean Sea: longitudinal trends. Deep-Sea Res 46:2025-2039

Ferrier C, Rassoulzadegan F (1991) Density-dependent effects of protozoans on specific growth rates in pico- and nanoplanktonic assemblages. Limnol Oceanogr 36: 657-669

Field JG, Clarke KR, Warwick RM (1982) A practical strategy for analysing multispecies distribution patterns. Mar Ecol Prog Ser 8:37-52

Gallegos CL (1989) Microzooplankton grazing on phytoplankton in the Rhode River, Maryland: nonlinear feeding kinetics. Mar Ecol Prog Ser 57:23-33

Gifford DJ (1985) Laboratory culture of marine planktonic oligotrichs (Ciliophora, Oligotrichida). Mar Ecol Prog Ser 23:257-267

Gifford DJ (1988) Impact of grazing by microzooplankton in the Northwest Arm of Halifax Harbour, Nova Scotia. Mar Ecol Prog Ser 47:249-258

Gray JS (2000) The measurement of marine species diversity, with an application to the benthic fauna of the Norwegian continental shelf. J Exp Mar Biol Ecol 250:23-49

Heinbokel JF, Beers JR (1979) Studies on the functional role of tintinnids in the Southern California Bight. III. Grazing impact of natural assemblages. Mar Biol 52:23-32

Jonsson PR (1986) Particle size selection, feeding rates and growth dynamics of marine planktonic oligotrichous ciliates (Ciliophora: Oligotrichina). Mar Ecol Prog Ser 33: 265-277

Jørgensen E (1924) Mediterranean Tintinnidae. Report on the Danish Oceanographical Expeditions 1908-1910 to the Mediterranean and adjacent seas II (Biology), J.3. Andr
Fred Host \& Son, Copenhagen

Kamiyama T (1994) The impact of grazing by microzooplankton in northern Hiroshima Bay, the Seto Inland Seam, Japan. Mar Biol 119:77-88

Kimor B, Wood EJ (1975) A plankton study in the Eastern Mediterranean Sea. Mar Biol 29:321-333

Kivi K, Setälä O (1995) Simultaneous measurement of food particle selection and clearance rates of planktonic oligotrich ciliates (Ciliophora: Oligotrichina). Mar Ecol Prog Ser 119:125-137

Klaas C (1997) Microprotozooplankton distribution and their potential grazing impact in the Antarctic Circumpolar Current. Deep-Sea Res II 44:375-393

Kopylov AI, Tumantseva NI (1987) Analysis of the contents of tintinnid food vacuoles and evaluation of their contribution to the consumption of phytoplankton production off the Peru coast. Oceanology 27:343-347

Krom MD, Kress N, Brenner S, Gordon LI (1991) Phosphorus limitation of primary productivity in the eastern Mediterranean Sea. Limnol Oceanogr 36:424-432

Krsinic F (1982) On vertical distribution of tintinnines (Ciliata, Oligotrichida, Tintinnina) in the open waters of the South Adriatic. Mar Biol 68:83-90

Krsinic F (1995) Changes in the microzooplankton assemblages in the northern Adriatic Sea during 1989 to 1992. J Plankton Res 17:935-953

Landry MR, Hassett RP (1982) Estimating the grazing impact of marine micro-zooplankton. Mar Biol 67:283-288

Landry MR, Kirshtein J, Constantinou J (1996) Abundances and distributions of picoplankton populations in the Central Equatorial Pacific from $12^{\circ} \mathrm{N}$ to $12^{\circ} \mathrm{S}, 140^{\circ} \mathrm{W}$. DeepSea Res II 43:871-890

Laval-Peuto M (1994) Classe des Oligotrichea Büstchli, 1887. Ordre des Tintinnida Kofoid et Campbell, 1929. In: Grassé PP (ed) Traité de Zoologie II, 2, Infusoires ciliés. Masson, Paris, p 181-219

Laval-Peuto M, Rassoulzadegan F (1988) Autofluorescence of marine planktonic Oligotrichina and other ciliates. Hydrobiologia 159:99-110

Laval-Peuto M, Grain J, Deroux G (1994) Classe des Oligotrichea Büstchli, 1887. Ordres des Oligotrichida Büstchli, 1887 et des Choreotrichida Small \& Lynn, 1985. In: Grassé PP (ed) Traité de Zoologie II, 2, Infusoires ciliés. Masson, Paris, p 153-179

Li WKW, Subba Rao DV, Harrison WG, Smith JC, Cullen JJ, Irwin B, Platt T (1983) Autotrophic picoplankton in the tropical ocean. Science 219:292-295

Lynn DH, Montagnes DJS, Small EB (1988) Taxonomic descriptions of some conspicuous species in the family Strombidiidae (Ciliophora: Oligotrichida) from the isles of Shoals, Gulf of Maine. J Mar Biol Assoc UK 68:259-276

Lynn DH, Montagnes DJS, Dale T, Gilron GL, Strom SL (1991) A reassessment of the genus Strombidinopsis (Ciliophora, Choreotrichida) with descriptions of four new planktonic species and remarks on its taxonomy and phylogeny. J Mar Biol Assoc UK 71:597-612

Maeda M (1986) An illustrated guide to the species of the families Halteriidae and Strobilidiidae (Oligotrichida, Ciliophora), free swimming protozoa common in the aquatic environment. Bull Ocean Res Inst 21:1-67

Maeda M, Carey PG (1985) An illustrated guide to the species of the family Strombidiidae (Oligotrichida, Ciliophora), free swimming protozoa common in the aquatic environment. Bull Ocean Res Inst 19:1-68

Marshall SM (1973) Respiration and feeding in copepods. Adv Mar Biol 11:57-120

Montagnes DJS, Taylor FJR (1994) The salient features of five 
marine ciliates in the Class Spirotrichea (Oligotrichia), with notes on their culturing and behaviour. J Eukaryot Microbiol 41:569-586

Montagnes DJS, Lynn DH, Stoecker DK, Small EB (1988) Taxonomic descriptions of one new species and redescription of four species in the Family Strombidiidae (Ciliophora, Oligotrichida). J Protozool 35:189-197

Montagnes DJS, Taylor FJR, Lynn DH (1990) Strombidium inclinatum n. sp. and a reassessment of Strombidium sulcatum Clarapède and Lachmann (Ciliophora). J Protozool 37:318-323

Paranjape MA (1987) Grazing by microzooplankton in the eastern Canadian arctic in summer 1983. Mar Ecol Prog Ser 40:239-246

Pérez MT, Dolan JR, Fukai E (1997) Planktonic oligotrich ciliates in the NW Mediterranean: growth rates and consumption by copepods. Mar Ecol Prog Ser 155:89-101

Pérez MT, Dolan JR, Vidussi F, Fukai E (2000) Diel vertical distribution of planktonic ciliates within the surface layer of the NW Mediterranean (May 1995). Deep-Sea Res 47 : 479-503

Peuto-Moreau M (1991) Symbiose plastidiale et mixotrophie des ciliés planctoniques marins Oligotrichina (Ciliophora). Thèse de Doctorat d' état, Université de Nice-Sophia Antipolis

Pierce RW, Turner JT (1992) Ecology of planktonic ciliates in marine food webs. Rev Aquat Sci 6:139-181

Pierce RW, Turner JT (1993) Global biogeography of marine tintinnids. Mar Ecol Prog Ser 94:11-26

Pitta P, Giannakourou A (2000) Planktonic ciliates in the oligotrophic Eastern Mediterranean: vertical, spatial distribution and mixotrophy. Mar Ecol Prog Ser 194:269-282

Platt T (1985) Phytoplankton production in oligotrophic marine ecosystems: the Mediterranean Sea. In: MoraitouApostolopoulou M, Kiortsis V (eds) Mediterranean marine ecosystems. Plenum Press, New York, p 231-246

Platt T, Rao DVS, Irwin B (1983) Photosynthesis of picoplankton in the oligotrophic ocean. Nature 300:702-704

Putt M, Stoecker DK (1989) An experimentally determined carbon: volume ratio for marine 'oligotrichous' ciliates from estuarine and coastal waters. Limnol Oceanogr 34: 1097-1103

Rassoulzadegan F (1977) Evolution annuelle des ciliés pélagiques en Méditerranée Nord-Occidentale. Ciliés oligotriches 'Non Tintinnides' (Oligotrichina). Ann Inst Océanogr Paris 53:125-134

Rassoulzadegan F (1978) Dimensions et taux d'ingestion des particules consommées par un Tintinnid: Favella ehrenbergii (Clap. \& Lachm.) Jörg., cilié pelagique marin. Ann Inst Océanogr Paris 54:17-24

Rassoulzadegan F (1979) Evolution annuelle des ciliés pélagiques en Méditerranée nord-occidentale. II. Ciliés Oligotriches. Tintinnides (Tintinnina). Invest Pesq 43:417-448

Rassoulzadegan F (1982) Dependence of grazing rate, gross growth efficiency and food size range on temperature in a pelagic Oligotrichous ciliate Lohmaniella spiralis Leeg., fed on naturally occuring particulate matter. Ann Inst Océanogr Paris 58:177-184

Rassoulzadegan F, Etienne M (1981) Grazing of the tintinnid Stenosemella ventricosa (Clap. \& Lachm.) Jörg. on the naturally occurring particulate matter from a Mediterranean neritic area. Limnol Oceanogr 26:258-270

Rassoulzadegan F, Laval-Peuto M, Sheldon RW (1988) Partitioning of the food ration of marine ciliates between pico- and nanoplankton. Hydrobiologia 159:75-88

Revelante N, Gilmartin M (1983) Microzooplankton distribution in the Northern Adriatic Sea with emphasis on the relative abundance of ciliated protozoans. Oceanol Acta 6: 407-415

Revelante N, Gilmartin M (1990) Vertical water column resource partitioning by a ciliated protozoan population under stratified conditions in the northern Adriatic. J Plankton Res 12:89-107

Riley GA (1956) Oceanography of long Island Sound, 1952-1954. IX. Production and utilization of organic matter. Bull Bingham Oceanogr Coll 15:324-341

Riley GA (1957) Phytoplankton of the North Central Sargasso Sea, 1950-52. Limnol Oceanogr 2:252-270

Rosenzweig ML (1995) Species diversity in space and time. Cambridge University Press, Cambridge

Sautour B, Artigas LF, Delmas D, Herbland A, Laborde P (2000) Grazing impact of micro- and mesozooplankton during a spring situation in coastal waters off the Gironde estuary. J Plankton Res 22:531-552

Sherr BF, Sherr EB, Rassoulzadegan F (1988) Rates of digestion of bacteria by marine phagotrophic protozoa: temperature dependence. Appl Environ Microbiol 54:1091-1095

Sherr EB, Sherr BF, Fallon RD, Newell SY (1986) Small, aloricate ciliates as a major component of the marine heterotrophic nanoplankton. Limnol Oceanogr 31:177-183

Sherr EB, Rassoulzadegan F, Sherr BF (1989) Bacterivory by pelagic choreotrichous ciliates in coastal waters of the NW Mediterranean Sea. Mar Ecol Prog Ser 55:235-240

Smetacek V (1981) The annual cycle of protozooplankton in the Kiel Bight. Mar Biol 63:1-11

Spittler P (1973) Feeding experiments with tintinnids. Oikos (Suppl) 15:128-132

Stelfox-Widdicombe CE, Edwards ES, Burkill PH, Sleigh MA (2000) Microzooplankton grazing activity in the temperate and sub-tropical NE Atlantic: summer 1996. Mar Ecol Prog Ser 208:1-12

Stoecker DK (1988) Are marine planktonic ciliates suspension feeders? J Protozool 35:252-255

Stoecker DK, Taniguchi A, Michaels AE (1989) Abundance of autotrophic, mixotrophic, and heterotrophic planktonic ciliates in shelf and slope waters. Mar Ecol Prog Ser 50: $241-254$

Stoecker DK, Buck KR, Putt M (1992) Changes in the sea-ice brine community during the spring-summer transition, McMurdo Sound, Antarctica. I. Photosynthetic protists. Mar Ecol Prog Ser 84:265-278

Strom S, Postel JR, Booth BC (1993) Abundance, variability, and potential grazing impact of planktonic ciliates in the open subarctic Pacific Ocean. Prog Oceanogr 32:185-203

Thompson GA, Alder VA, Boltovskoy D, Brandini F (1999) Abundance and biogeography of tintinnids (Ciliophora) and associated microzooplankton in the Southwestern Atlantic Ocean. J Plankton Res 21:1265-1298

Turley CM, Bianchi M, Christaki U, Conan P, Harris JRW, Psarra S, Ruddy G, Stutt ED, Tselepides A, Van Wambeke F (2000) Relationship between primary producers and bacteria in an oligotrophic sea-the Mediterranean and biogeochemical implications. Mar Ecol Prog Ser 193: 11-18

Verity PG (1987) Abundance, community composition, size distribution, and production rates of tintinnids in Narragansett Bay, Rhode Island. Estuar Coast Shelf Sci 24: $671-690$

Submitted: October 27, 2000; Accepted: March 22, 2001

Proofs received from author(s): June 20, 2001 